\title{
Technetium Chemistry in HLW
}

\section{Progress Report}

Principal Investigator:

Co-Investigators:

Nancy J. Hess

Pacific Northwest National Laboratory

PO Box 999, P7-50

Richland WA 99352

509/376-9808 phone

509/372-1632 fax

nancy.hess@pnl.gov

Andrew R. Felmy

Pacific Northwest National Laboratory

PO Box 999, K8-96

Richland WA 99352

509/376-4079 phone

509/376-3650 fax

Andy.felmy@pnl.gov

Kevin M. Rosso

Pacific Northwest National Laboratory

PO Box 999, K8-96

Richland WA 99352

509/376-7762 phone

509/376-3650 fax

Kevin.rosso@pnl.gov

Yuanxian Xia

Pacific Northwest National Laboratory

PO Box 999, P7-50

Richland WA 99352

509/373-5767 phone

509/372-1632 fax

yuanxian.xia@pnl.gov 


\section{Research Objective}

Tc contamination is found within the DOE complex at those sites whose mission involved extraction of plutonium from irradiated uranium fuel or isotopic enrichment of uranium. At the Hanford Site, chemical separations and extraction processes generated large amounts of high level and transuranic wastes that are currently stored in underground tanks. The waste from these extraction processes is currently stored in underground High Level Waste (HLW) tanks. However, the chemistry of the HLW in any given tank is greatly complicated by repeated efforts to reduce volume and recover isotopes. These processes ultimately resulted in mixing of waste streams from different processes. As a result, the chemistry and the fate of Tc in HLW tanks are not well understood. This lack of understanding has been made evident in the failed efforts to leach Tc from sludge and to remove Tc from supernatants prior to immobilization. Although recent interest in Tc chemistry has shifted from pretreatment chemistry to waste residuals, both needs are served by a fundamental understanding of Tc chemistry.

The fate of Tc in the insoluble salts that constitute tank residuals is of paramount importance due to the long half-life and environmental mobility of Tc. Knowledge gaps include determination of the Tc oxidation state, the stability of reduced Tc solution species, and interactions with possible organic complexants in HLW. The objective of this renewal proposal is to continue to pursue fundamental understanding of Tc solution chemistry that provides the basis to make knowledgeable decisions and predictions of Tc behavior during retrieval operations and in tank residuals.

We propose to undertake three main tasks in this renewal proposal:

- Continued investigation of the stability of the Tc-organic complexes over a range of $\mathrm{pH}$, ionic strength, and as a function of ligand concentration.

- Continued investigation of reduced Tc-carbonate complexes at environmentally relevant $\mathrm{pH}$ conditions.

- Investigation of the stability of the Tc-oxalate complex in support of HLW sludge retrieval efforts.

The results of the proposed work will provide the basis for understanding Tc chemistry in HLW that is necessary for waste retrieval processing, accessing the long-term risk of HLW tank residuals, and the design of pretreatment strategies, if necessary.

\section{Research Progress and Implications}

Significant accomplishments were achieved during the four years of funding. Several of these results have been published or submitted for journal publication. Much of the success we have attained in this research project can be attributed to ability to maintain rigorous reducing conditions over extended periods of time. In our solubility studies of Tc(IV) aqueous solution chemistry, a significant proportion, typically more than $85 \%$, of Tc in solution is present as $\mathrm{Tc}(\mathrm{IV})$. In contrast, previous studies were conducted in the presence of up to $100 \mathrm{X}$ excess of $\mathrm{Tc}(\mathrm{VII})$. In addition, we have emphasized spectroscopic characterization of solution and solid phase species to validate predictions based on thermodynamic data derived from the solubility studies. The predominance of Tc(IV) solution species has been essential for spectroscopic investigations (UV-Vis and XAS), which greatly facilitate interpretation of our solubility studies.

-We are in the process of conducting a detail experimental and theoretical spectrophotometric study of the $\mathrm{TcO}(\mathrm{OH})_{3}{ }^{-}$and $\mathrm{TcO}(\mathrm{OH})_{4}{ }^{2-}$ species under basic conditions. We first observed these 
species in our earlier solubility studies of $\mathrm{TcO}_{2} \cdot n \mathrm{H}_{2} \mathrm{O}(\mathrm{am})$ to $3 \mathrm{M} \mathrm{NaOH}$, where weak amphoteric behavior of Tc(IV) to $\mathrm{pH} 12$ has been observed in the absence of complexing ligands. Once these are completed we will conduct analog studies in the presence of variable concentrations of dissolved $\mathrm{CO}_{2}$ to understand the formation of Tc(IV)-carbonate complexes at nearly neutral $\mathrm{pH}$ conditions.

- Solvent extraction method was used to determine the stability constants of Tc(IV) with oxalate anions in $\mathrm{NaCl}$ solutions ranging in concentration from $0.5 \mathrm{M}$ to $2.0 \mathrm{M}$. The distribution ratio of $\mathrm{Tc}(\mathrm{IV})$ between the organic and aqueous phases was found to decrease as the concentration of oxalic acid increased. At the oxalic acid concentrations used in these experiments, the complexes $\mathrm{TcO}(\mathrm{Ox})$ and $\mathrm{TcO}(\mathrm{Ox})_{2}{ }^{2-}$ were found to be the dominant aqueous species. Based on these data, the thermodynamic stability constants of Tc(IV) with oxalate complexes were calculated by the Specific Ion Interaction Theory (SIT). The thermodynamic stability constants of Tc(IV) with oxalate complexes were calculated by the SIT model to be $\log \beta^{\circ}{ }_{101}=7.22 \pm 0.17$ for the formation of TcOOx $\left(\mathrm{TcO}^{2+}+\mathrm{Ox}^{2-}=\mathrm{TcO}(\mathrm{Ox}), \log \beta^{\mathrm{o}}{ }_{102}=11.08 \pm 0.19\right.$ for the formation of $\mathrm{TcO}(\mathrm{Ox})_{2}{ }^{2-}\left(\mathrm{TcO}^{2+}+2 \mathrm{Ox}^{2-}=\mathrm{TcO}(\mathrm{Ox})_{2}{ }^{2-}\right)$, respectively. The data are comparable but a little weaker than what has been observed for $\mathrm{VO}^{2+}$ and $\mathrm{UO}_{2}{ }^{2+}$. No data are available for the stability constants of Tc(IV)-oxalate complexes in the literature. The results indicate that the oxalate anion forms strong complexes with technetium (IV) ion as a function of ionic strength in $\mathrm{NaCl}$ solutions. These results will help us to assess the efficiency of tank waste retrieval methods for technetium as well as the long-term mobility in the environment. In order to understand the chemical behavior of technetium with oxalic acid, an integrated approach of solvent extraction, spectroscopic, solubility measurements of $\mathrm{TcO}_{2}(\mathrm{am})$ and thermodynamic models in multielectrolyte systems has been initiated.

- Last year an extensive Raman microprobe investigation into the structure of $\mathrm{TcO}_{2} \cdot n \mathrm{H}_{2} \mathrm{O}(\mathrm{am})$ as a function of $\mathrm{pH}$ was conducted however the vibrational spectroscopic results were not conclusive due in part to the weak Raman scattering and tendency for the $\mathrm{TcO}_{2} \cdot n \mathrm{H}_{2} \mathrm{O}(\mathrm{am})$ to transform under the focused laser beam. Analysis of the Extended X-ray Absorption Fine Structure (EXAFS) indicates changes in the local $\mathrm{TcO}_{2} \cdot n \mathrm{H}_{2} \mathrm{O}(\mathrm{am})$ structure however full interpretation of the EXAFS data remains problematic. We plan to continue these studies using total x-ray and neutron diffraction studies at Stanford Synchrotron Research Laboratory and Los Alamos Neutron Science Center .

\section{Planned Activities}

We have three new experimental tasks outlined for FY06: 1) detailed spectrophotometric study of the $\mathrm{TcO}(\mathrm{OH})_{3}{ }^{-}$and $\mathrm{TcO}(\mathrm{OH})_{4}{ }^{2-}$ species under basic conditions in the absence and presence of $\mathrm{CO}_{2}$, solubility studies of $\mathrm{TcO}_{2} \cdot n \mathrm{H}_{2} \mathrm{O}(\mathrm{am})$ as a function of $\mathrm{pH}$ in the presence of oxalate under midly acidic conditions, and continued investigations of the structure of Tc precipitates under alkaline conditions. Our spectrophotometric study $\mathrm{TcO}(\mathrm{OH})_{3}{ }^{-}$and $\mathrm{TcO}(\mathrm{OH})_{4}{ }^{2-}$ species will continue throughout FY06. The solubility studies of $\mathrm{TcO}_{2} \cdot n \mathrm{H}_{2} \mathrm{O}(\mathrm{am})$ in the presence of oxalate are near completion. Continued investigation of the structure of $\mathrm{TcO}_{2} \cdot n \mathrm{H}_{2} \mathrm{O}(\mathrm{am})$ will likely continue throughout FY06 and FY07.

A continuing task from FY05 is the refinement of solvent extraction conditions for solutions with hydroxide concentrations approaching $5 \mathrm{M} \mathrm{NaOH}$. Currently we use tetraphenylphosphonium chloride and chloroform as the organic phase which extracts anionic Tc(VII), as $\mathrm{TcO}_{4}^{-}$, into the organic phase and leaves the various Tc(IV) species in the aqueous phase under a wide range of 
pH conditions. However, at high hydroxide concentration we have observed the co-extraction of anionic $\mathrm{Tc}(\mathrm{IV})$ species, such as $\mathrm{TcO}(\mathrm{OH})_{3}{ }^{-}$, with $\mathrm{TcO}_{4}{ }^{-}$into the organic phase concomitant with a decrease in the distribution coefficient for Tc(VII). We have tried various strategies to exclusively extract Tc(VII) into the organic phase and increase the extraction efficency. These are mainly based on $\mathrm{pH}$ adjustment of the solution immediately preceding extraction. This approach necessitates the addition of highly concentrated acid that in turn further reduces the efficiency of the extraction of Tc(VII) in to the organic phase. We will investigate the use of ligands to prevent the extraction of Tc(IV) in to the organic phase. This work will continue through September 2004.

\section{Information Access}

Three journal articles and one technical report are in various stages of publication. In addition several presentations were made. These are listed below.

\section{Publications}

- "Stability constants of Tc(IV) oxalate complexes as a function of ionic strength," by Y. Xia, N.J. Hess, and A.R. Felmy, Journal of Solution Chemistry, in press.

- "A thermodynamic model for the solubility of $\mathrm{TcO}_{2} \cdot \mathrm{xH}_{2} \mathrm{O}(\mathrm{am})$ in the aqueous $\mathrm{Tc}(\mathrm{IV})-$ $\mathrm{Na}^{+}-\mathrm{Cl}^{-}-\mathrm{H}^{+}-\mathrm{OH}^{-}-\mathrm{H}_{2} \mathrm{O}$ system," by N.J. Hess, Y. Xia, D. Rai, and S.D. Conradson. Journal of Solution Chemistry 33:199-227, 2004.

- "Solubility of $\mathrm{TcO}_{2} \cdot \mathrm{H}_{2} \mathrm{O}(\mathrm{am})$ in the presence of gluconate in aqueous solution," by N.J. Hess, Y. Xia, and A.R. Felmy, to be published in American Chemical Society Proceedings Volume entitled "Nuclear Waste Remediation: Accomplishments of the Environmental Management Science Program,” in press.

- "Bond valence sums for Tc-O system from EXAFS data," by D.W. Wester and N.J. Hess, Inorganic Chimica Acta, 358(4):865-874 (2005).

- "Hanford Tanks 241-AY-102 and 241-BX-101: Sludge Composition and Contaminant Release Data," by Krupka et al. PNNL Technical Report, 2004.

\section{Presentations}

- "Solubility of $\mathrm{TcO}_{2} \cdot \mathrm{xH}_{2} \mathrm{O}(\mathrm{am})$ in the presence of gluconate in aqueous solution." Invited presentation at 2003 ACS Annual Meeting.

- "Technetium in HLW: An example of environmental science at PNNL." Invited presentation in Merida, Mexico on May $26^{\text {th }} 2003$.

- "Technetium Chemistry in HLW: Role of Organic Complexants." 2003 EMSP HLW Annual Workshop.

- "Technetium Chemistry in HLW: Role of Organic Complexants." FY02 EMSP High Level Waste Workshop. 